\title{
Variability of Haemolysin(s) Produced by Vibrio vulnificus
}

\author{
By KENJI OKADA, * SHUNJI MIAKE, TETSUHIRO MORIYA, \\ MASAO MITSUYAMA AND KAZUNOBU AMAKO \\ Department of Bacteriology, Faculty of Medicine, Kyushu University, Fukuoka 812, Japan
}

(Received 30 January 1987; revised 27 May 1987)

\begin{abstract}
The peptide composition and antigenic cross-reactivity of partially purified and concentrated haemolysins of 16 strains of Vibrio vulnificus were examined by SDS-PAGE and immunoblotting analysis, using a monoclonal antibody (MAb), 6F8D, raised against the haemolysin. All strains produced a common peptide of $36 \mathrm{kDa}$ and the $\mathrm{MAb}$ reacted with this peptide. In some strains, larger molecules, including a $56 \mathrm{kDa}$ peptide, were produced, but the MAb did not react with this peptide. The haemolytic activity of the strains was effectively neutralized by the MAb, except in the case of strains producing the $56 \mathrm{kDa}$ peptide. These findings indicate that the 36 $\mathrm{kDa}$ haemolysin is common to all 16 strains and that $V$. vulnificus can produce a second haemolysin which differs in molecular mass and antigenicity.
\end{abstract}

\section{INTRODUCTION}

Since Vibrio vulnificus (originally known as Beneckea vulnificus and lactose-positive Vibrio) was reported by Reichelt et al. (1976) and Hollis et al. (1976) to cause severe wound infection and sepsis, virulence factors of this organism have been examined. It was reported that this bacterium could produce various kinds of extracellular products responsible for haemolysis, namely a phospholipase A2 and lysophospholipase (Testa et al., 1984), and cytolysin (Kreger \& Lockwood, 1981; Gray \& Kreger, 1985) or haemolysin (Tison \& Kelly, 1984; Shinoda et al., 1985). Gray \& Kreger (1985) reported that purified cytolysin of $V$. vulnificus had a molecular mass of about $56 \mathrm{kDa}$, as estimated by SDS-PAGE and by amino acid analysis.

In a previous study (Okada et al., 1987), we described a monoclonal antibody (MAb) to the haemolysin produced from $V$. vulnificus strain FCC, which was different from the strain used by Gray \& Kreger (1985) for the purification of the cytolysin. This MAb recognized a $36 \mathrm{kDa}$ peptide produced by strain FCC. These findings and those of Gray \& Kreger (1985) suggested the existence of at least two distinct types of haemolysins in $V$. vulnificus. Here we report comparative studies by SDS-PAGE and immunoblotting to investigate possible heterogeneity in the molecular mass of the haemolysin.

\section{METHODS}

Bacteria. The strains of Vibrio vulnificus used are listed in Table 1. Strain FCC was used for the production of MAbs to the haemolysin. All 16 strains were maintained on slants of heart infusion agar (Eiken Kagaku Co.) supplemented with $3 \%(\mathrm{w} / \mathrm{v}) \mathrm{NaCl}$.

Preparation of haemolysin. Strains were cultured in heart infusion broth at $37^{\circ} \mathrm{C}$ for $8 \mathrm{~h}$, with shaking. After removing the organisms by centrifugation $(16000 \mathrm{~g}, 30 \mathrm{~min})$, ammonium sulphate was added to the pooled culture supernates $(400 \mathrm{ml})$ to $40 \%$ saturation $\left(282 \mathrm{~g} \mathrm{l}^{-1}\right)$ and the preparation was then stirred overnight with a magnetic stirrer. The precipitate was recovered by centrifugation $(16000 \mathrm{~g}$, for $20 \mathrm{~min}$ ) and dissolved in phosphate-bufferedsaline (PBS: $\mathrm{NaCl} 8.0 \mathrm{~g}, \mathrm{KCl} 0.2 \mathrm{~g}, \mathrm{Na}_{2} \mathrm{HPO}_{4} .12 \mathrm{H}_{2} \mathrm{O} 2.9 \mathrm{~g}, \mathrm{KH}_{2} \mathrm{PO}_{4} 0.2 \mathrm{~g} \mathrm{l}^{-1} ; \mathrm{pH} \mathrm{7.2)}$.

Production of $M A$ Abs. The production and characterization of MAbs against the haemolysin produced by $V$. vulnificus strain FCC was as described by Okada et al. (1987). Briefly, BALB/c mice were injected subcutaneously

Abbreviations: MAb, monoclonal antibody; SRBC, sheep red blood cells. 


\section{Table 1. Strains of V. vulnificus studied}

\begin{tabular}{|c|c|c|}
\hline Strain & Source & Donor or reference \\
\hline FCC & Blood and wound & Amako et al. (1984) \\
\hline SAN & Blood & I. Azuma \\
\hline MK & Knee joint fluid & T. Ishihara \\
\hline FS & Blood & T. Ishihara \\
\hline E-18 & Sea water & I. Azuma \\
\hline ATCC 27562 & Type strain & Amako et al. (1984) \\
\hline CDC B 3547 & Leg wound & Shinoda et al. (1985) \\
\hline B 1931 & Blood & S. Shinoda \\
\hline M 2799 & Wound & S. Shinoda \\
\hline $371 \mathrm{Op}$ & Sea food & Yoshida et al. (1985) \\
\hline $371 \mathrm{Tr}$ & Sea food & Yoshida et al. (1985) \\
\hline $374 \mathrm{Op}$ & Blood & Yoshida et al. (1985) \\
\hline $374 \mathrm{Tr}$ & Blood & Yoshida et al. (1985) \\
\hline$L-1$ & Bone marrow & Yoshida et al. (1985) \\
\hline L-180 & Bone marrow & Yoshida et al. (1985) \\
\hline C-4113 & Unknown & S. Yoshida \& Y. Mizug \\
\hline
\end{tabular}

with $200 \mu \mathrm{g}$ of the haemolysin on days 1,7 and 14. Three days before killing the mice, a final booster injection of $100 \mu \mathrm{g}$ haemolysin was given intravenously. Hybridomas were made by fusing the spleen cells with the P3U1 myeloma cell line, according to the procedure described by Harn et al. (1984). The antibody-producing cells were screened by the neutralization test for haemolysin. The hybridomas were injected into pristane-primed mice and the ascites was used as the source of MAbs after precipitation with ammonium sulphate. The precipitate was dissolved in $10 \mathrm{ml}$ PBS and dialysed. Clone 6F8D was used in the present study.

Haemolysin assay. The method was described in the previous paper (Okada et al., 1987). Briefly, serially diluted haemolysin preparation $(50 \mu \mathrm{l})$ was mixed in 96 -well microtitre plates with $50 \mu \mathrm{l}$ of a $1 \%(\mathrm{v} / \mathrm{v})$ sheep red blood cell (SRBC) suspension in PBS. The plates were incubated at $37^{\circ} \mathrm{C}$ for $1 \mathrm{~h}$ and the haemolysin titre was defined as the reciprocal of the highest dilution of haemolysin that showed complete haemolysis.

Neutralization of haemolysin by MAb. The method of the neutralization test was basically the same as that described by Okada et al. (1987). Briefly, twofold-diluted MAb $(50 \mu \mathrm{l})$ was added to crude haemolysin preparation in a 96-well microtitre plate. The amount of the crude haemolysin was adjusted to the concentration that induced complete haemolysis. After incubation at $37^{\circ} \mathrm{C}$ for $30 \mathrm{~min}, 50 \mu \mathrm{l}$ of $1 \%$ (v/v) SRBC was added to the wells. The plates were incubated at $37^{\circ} \mathrm{C}$ for $1 \mathrm{~h}$ and the inhibition titre was defined as the reciprocal of the highest dilution of MAb that inhibited the complete haemolysis.

SDS-PAGE. This was done by the method of Laemmli (1970), with the modifications described by Okada et al. (1987).

Immunoblotting procedures. These were as described by Okada et al. (1987).

\section{RESULTS AND DISCUSSION}

$S D S-P A G E$ profiles of the haemolysins

Gray \& Kreger (1985) reported that an extracellular cytolysin of $V$. vulnificus had a molecular mass of about $56 \mathrm{kDa}$, which is larger than the haemolysin $(36 \mathrm{kDa})$ produced by strain FCC used in this work. To clarify this discrepancy, the peptides of the haemolysin from various strains were analysed. Crude haemolysins were prepared from ammonium sulphate precipitates of culture supernates. The peptide profiles of the crude haemolysins produced by six strains of $V$. vulnificus from various sources are shown in Fig. 1 . One peptide band at $36 \mathrm{kDa}$ was common to all six strains (Fig. 1, arrowhead). In addition to this band, strains ATCC 27562 and SAN (which produced more proteins than the other strains) showed two more strongly stained bands at 56 and $60 \mathrm{kDa}$ (Fig. 1, lanes 3 and 4). The $56 \mathrm{kDa}$ peptide, which corresponded to the peptide reported by Gray \& Kreger (1985), was undetectable or very faint in the other four strains. Strains FS and E-18 had one more band at $20 \mathrm{kDa}$ (Fig. 1, lanes 6 and 7). These data suggest the possibility that two types of haemolysin are produced by $V$. vulnificus. Some strains produced both 56 and $36 \mathrm{kDa}$ haemolysins and the others produced only the $36 \mathrm{kDa}$ haemolysin. The significance of the low-molecular-mass peptide produced by strains FS and E-18 was not elucidated. 


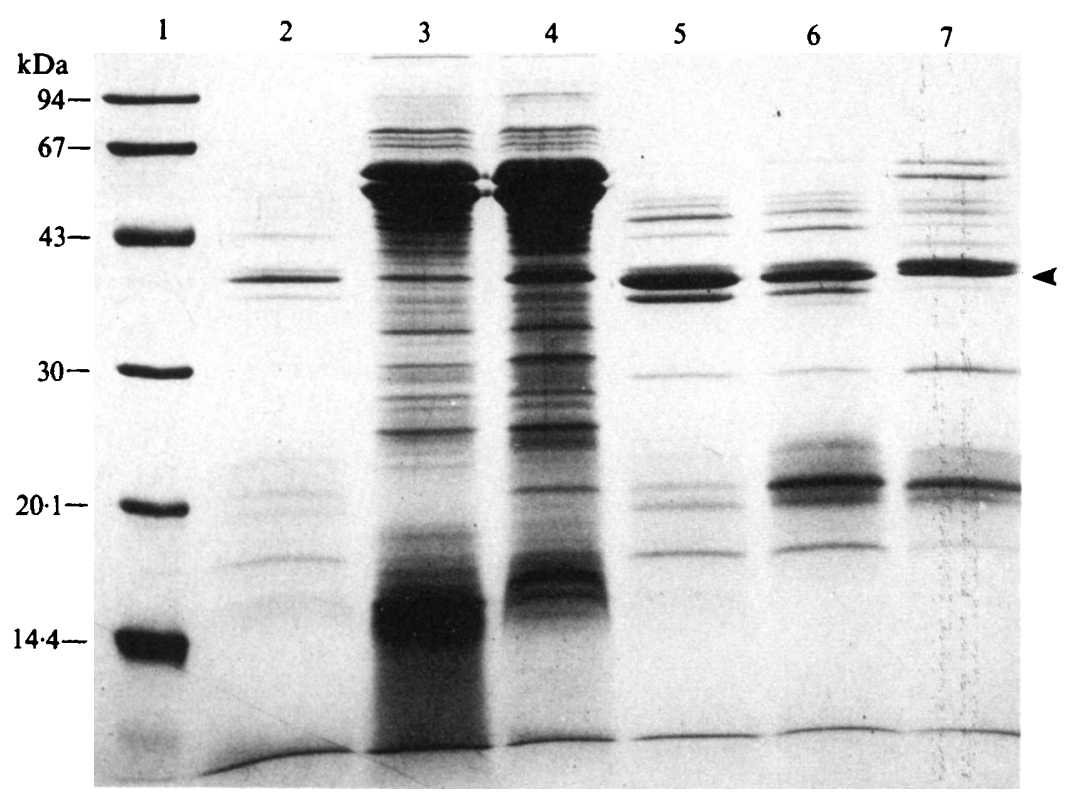

Fig. 1. SDS-PAGE of the extracellular haemolysin preparations from six representative strains of $V$.vulnificus. Samples were denatured under reducing conditions (2-mercaptoethanol in the solubilizing buffer). Lanes: 1, molecular mass markers (Pharmacia); 2, strain FCC; 3, strain ATCC 27562; 4, strain $\mathrm{SAN} ; 5$, strain MK ; 6, strain FS; strain E-18. The amount of samples was $80 \mu \mathrm{l}$ per lane. The gel was stained with Coomassie brilliant blue R-250. The arrow indicates the $36 \mathrm{kDa}$ band that was recognized by MAb 6F8D.

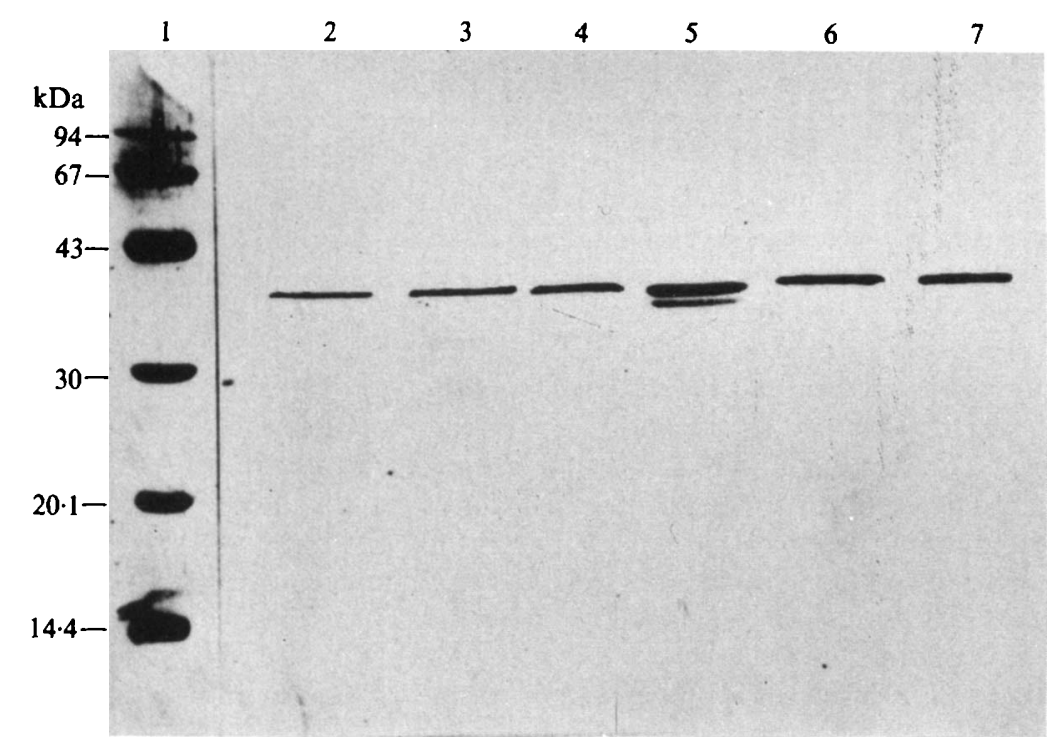

Fig. 2. Immunoblot analysis with MAb 6F8D. The haemolysin preparations were separated on SDSPAGE and after electrophoretic transfer to nitrocellulose paper, the strip was incubated for 90 min with a 1 in 100 dilution of MAb 6F8D ascites. Lanes: 1 , molecular mass markers that were transferred and stained with Amido black; $2-7$, as in Fig. 1. The sheet was probed with horseradish peroxidaseconjugated goat anti-mouse immunoglobulins $G$. 


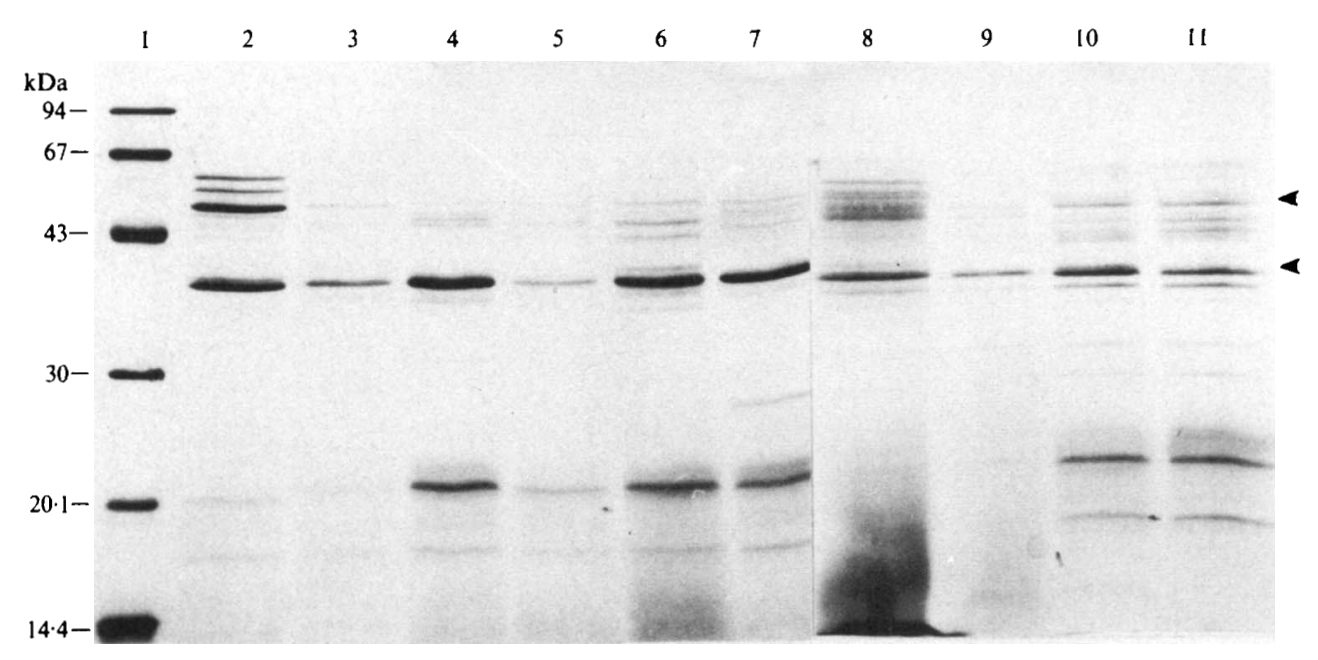

Fig. 3. SDS-PAGE of the extracellular haemolysin preparations from 10 other strains of $V$. vulnificus. Lanes: 1, molecular mass markers (Pharmacia); 2, strain B 3547; 3, strain B 1931; 4, strain M 2799;5, strain L-1; 6, strain L-180; 7, strain C-4123; 8, strain 371 Op; 9, strain 371 Tr; 10, strain 374 Op; 11, strain $374 \mathrm{Tr}$; the amount of samples was $100 \mu \mathrm{l}$ per lane. The gels were stained with Coomassie brilliant blue R-250. The upper arrowhead indicates the $56 \mathrm{kDa}$ band reported by Gray \& Kreger (1985), which is faint or undetectable in all lanes except lane 2 . The lower arrowhead indicates the $36 \mathrm{kDa}$ band, present in all lanes, that was recognized by $\mathrm{MAb} 6 \mathrm{~F} 8 \mathrm{D}$.

\section{Reactivity of anti-haemolysin $\mathrm{MAb}$ to the 56 and $36 \mathrm{kDa}$ peptides}

To investigate the antigenic cross-reactivity between the 56 and the $36 \mathrm{kDa}$ peptides, their reaction with $\mathrm{MAb} 6 \mathrm{~F} 8 \mathrm{D}$ was examined by immunoblotting. Immunoperoxidase staining revealed that only the $36 \mathrm{kDa}$ peptide reacted with the $6 \mathrm{~F} 8 \mathrm{D}$ antibody (Fig. 2). These data indicate that the $36 \mathrm{kDa}$ peptide from the six strains shared a common antigenic epitope and that there was no cross-reactive epitope revealed by MAb 6F8D on the $56 \mathrm{kDa}$ peptide.

\section{Neutralization of haemolysin activity by $M A b$}

To determine whether a peptide other than the $36 \mathrm{kDa}$ species was responsible for haemolytic activity, neutralization tests of the haemolytic activity with MAb 6F8D were done. The haemolytic activity was effectively neutralized in four strains which did not produce the $56 \mathrm{kDa}$ peptide, but was not neutralized in strains ATCC 27562 and SAN, which produced highmolecular-mass peptides (Table 2). This result indicates that strains ATCC 27562 and SAN produce another haemolysin which differs from that reactive to MAb 6F8D. This other haemolysin may be identical to the $56 \mathrm{kDa}$ peptide reported by Gray \& Kreger (1985).

To confirm whether the difference in the haemolysins was due to strain differences, a comparative study with 10 other strains was done. When crude haemolysin preparations obtained by ammonium sulphate precipitation were analysed by SDS-PAGE, all 10 strains were seen to produce the $36 \mathrm{kDa}$ peptide, although the staining intensities differed among the strains (Fig. 3). Of these 10 strains, only strain B 3547 had a strongly stained band at $56 \mathrm{kDa}$ (Fig. 3, lane 2). The $56 \mathrm{kDa}$ peptide in the other strains was faint. These data indicate that $V$. vulnificus produces mainly $36 \mathrm{kDa}$ haemolysin and some strains produce an additional haemolysin of 56 $\mathrm{kDa}$.

Tison et al. (1982) classified $V$. vulnificus into two biogroups. They reported that $V$. vulnificus strains isolated from diseased eels differed from the type strain of the species (ATCC 27562), in respect of indole production. They proposed that strains phenotypically similar to the type strain be classified as biogroup 1 (indole production positive), and that strains phenotypically similar to those isolated from diseased eels (ATCC 33148) be classified as biogroup 2. All strains used in 
Table 2. Neutralization of haemolysins from six representative strains of $V$. vulnificus by $M A b 6 F 8 D$

Serially twofold-diluted monoclonal antibody $(50 \mu \mathrm{l})$ was added to $50 \mu \mathrm{l}$ haemolysin. The haemolysins were adjusted to the concentration that gave complete haemolysis. After incubation at $37^{\circ} \mathrm{C}$ for $30 \mathrm{~min}$, $50 \mu 11 \%$ SRBC was added to the wells. The plates were incubated at $37^{\circ} \mathrm{C}$ for $1 \mathrm{~h}$. The inhibition titre was defined as the reciprocal of the highest dilution of antibody that inhibited haemolysis.

$\begin{array}{lcc}\text { Source of haemolysin } & \overbrace{\text { Expt 1 }}^{\text {Haemolytic-inhibition titre }} \\ \text { FCC } & 2048 & \text { Expt 2 } \\ \text { ATCC } 27562 & 32 & 512 \\ \text { SAN } & - & 16 \\ \text { MK } & 4196 & 32 \\ \text { FS } & 4196 & 2048 \\ \text { E-18 } & 2048 & 2048 \\ & & 1024\end{array}$

the present study produced indole (data not shown). These data suggest that there is little relationship between biogroups of the bacteria and types of haemolysins produced.

We thank M. Ohara for comments on the manuscript.

\section{REFERENCES}

Amako, K., OKada, K. \& Miake, S. (1984). Evidence for the presence of a capsule in Vibrio vulnificus. Journal of General Microbiology 130, 2741-2743.

Gray, L. D. \& Kreger, A. S. (1985). Purification and characterization of an extracellular cytolysin produced by Vibrio culnificus. Infection and Immunity 48, 62-72.

HaRn, D. A., Mitsuyama, M. \& David, J. R. (1984). Schistosoma mansoni anti-egg monoclonal antibodies protect against cercarial challenge in vitro. Journal of Experimental Medicine 159, 1371-1387.

Hollis, D. G., Weaver, R. E., Baker, C. N. \& THORNSBERRY, C. (1976). Halophilic Vibrio species isolated from blood cultures. Journal of Clinical Microbiology 3, 425-431.

KREGER, A. \& LoCkwOOD, D. (1981). Detection of extracellular toxin(s) produced by Vibrio vulnificus. Infection and Immunity 33, 583-590.

LAEMMLI, U. K. (1970). Cleavage of structural proteins during the assembly of the head of bacteriophage T4. Nature, London 227, 680-685.

Okada, K., Mitsuyama, M., Miake, S. \& Amako, K. (1987). Monoclonal antibodies against the haemolysin of Vibrio vulnificus. Journal of General Microbiology 133, 2279-2284.

Reichelt, J. L., BaumanN, P. \& BaumanN, L. (1976). Study of genetic relationships among marine species of the genera Beneckea and Photobacterium by means of DNA/DNA hybridization. Archives of Microbiology 110, 101-120.

Shinoda, S., Miyoshi, S., Yamanaka, H. \& NakaHARA, N. M. (1985). Some properties of Vibrio vulnificus hemolysin. Microbiology and Immunology 29, 583-590.

Testa, J., Daniel, L. W. \& Kreger, A. S. (1984). Extracellular phospholipase A2 and lysophospholipase produced by Vibrio vulnificus. Infection and Immunity 45, 458-463.

Tison, D. L. \& Kelly, M. T. (1984). Factors affecting hemolysin production by Vibrio vulnificus. Current Microbiology 10, 640-646.

Tison, D. L., Nishibuchi, M., Greenwood, J. D. \& SEIDER, R. J. (1982). Vibrio vulnificus biogroup 2: new biogroup pathogenic for eels. Applied and Environmental Microbiology 44, 640-646.

Towbin, H., Staehelin, T. \& Gordon, J. (1979). Electrophoretic transfer of proteins from polyacrylamide gels to nitrocellulose sheets: procedure and some applications. Proceedings of the National Academy of Sciences of the United States of America 79, 4350-4354.

Yoshida, S., Ogawa, M. \& Mizuguchi, Y. (1985). Relation of capsule materials and colony to virulence of Vibrio vulnificus. Infection and Immunity 47, 446451 . 